\title{
Prefabricated vertical drains (PVDs) in soft Bangkok clay: a case study of the new Bangkok International Airport project
}

\author{
Dennes T. Bergado, A.S. Balasubramaniam, R. J onathan Fannin, and \\ Robert D. Holtz
}

\begin{abstract}
This paper presents the performance of a full-scale test embankment constructed on soft Bangkok clay with prefabricated vertical drains (PVDs) at the site of the new Bangkok International Airport in Thailand. The embankment was square in plan with a maximum height of $4.2 \mathrm{~m}, 3 \mathrm{H}: 1 \mathrm{~V}$ side slopes, and base dimensions of $40 \mathrm{~m}$ by $40 \mathrm{~m}$. The piezometric level with depth is characterized by negative drawdown starting at around $8-10 \mathrm{~m}$ depth caused by excessive withdrawal of groundwater. Instrumentation was provided to monitor both horizontal and vertical movements of the test embankment. The measured increases in undrained shear strengths with depth are in agreement with the values calculated from the SHANSEP technique. The secondary compression ratio, $C_{\alpha}$, was 0.018 , or within the normal values for marine clays. The coefficient of horizontal consolidation measured in the field, $C_{\mathrm{h}(\mathrm{field})}$, was higher for soil at 4 and $10 \mathrm{~m}$ depths than for the weakest soil at $6 \mathrm{~m}$ depth. The back-calculated $C_{\mathrm{h} \text { (field) }}$ values range from 3 to $8 \mathrm{~m}^{2} / \mathrm{year}$, and the ratio of $C_{\mathrm{h} \text { (field) }}$ to $C_{\mathrm{h}(\mathrm{lab})}$ ranges from 4 to 5 , where $C_{\mathrm{h}(\mathrm{lab})}$ is the coefficient of horizontal consolidation measured in the laboratory. The degree of consolidation estimated from the pore-pressure dissipation measurements agreed with those obtained from settlement measurements. The water-content reductions from field measurements were also in good agreement with the values computed from the consolidation settlements. The full-scale study confirmed that the magnitudes of consolidation settlements increased with the corresponding decrease of PVD spacing at a particular time period. Lastly, the results of the full-scale study have proven the effectiveness of PVDs for the improvement of soft Bangkok clay.
\end{abstract}

Key words: soft clay, consolidation, prefabricated vertical drain, preloading, test embankment.

Résumé : Cet article décrit le comportement d'un remblai d'essai grandeur nature construit sur l'argile molle de Bangkok avec des drains verticaux préfabriqués (PVD) sur le site du New Bangkok International Airport (NBIA) en Thaïlande. Le remblai était de forme carrée en plan avec un hauteur maximale de 4,2 $\mathrm{m}$, des pentes de 3:1 et des dimensions de $40 \mathrm{~m} \times 40 \mathrm{~m}$ à la base. Le niveau piézométrique en fonction de la profondeur est caractérisé par un gradient négatif vers le bas commençant à environ $8 \mathrm{~m}$ à $10 \mathrm{~m}$ de profondeur à cause d'un prélèvement excessif de l'eau souterraine. L'instrumentation fournie permettait de mesurer les mouvements tant horizontaux que verticaux du remblai d'essai. Les augmentations mesurées de la résistance au cisaillement non drainé en fonction de la profondeur concordaient avec les valeurs calculées au moyen de la technique SHANSEP. On a trouvé que le rapport de compression secondaire $C_{\alpha}$ était de 0,018 , soit à l'intérieur des valeurs normales pour les argiles marines. Les valeurs de $C_{\mathrm{h}}$ (chantier) à des profondeurs de $4 \mathrm{~m}$ et $10 \mathrm{~m}$ sont plus élevées que dans le sol le plus mou à la profondeur de $6 \mathrm{~m}$. Les

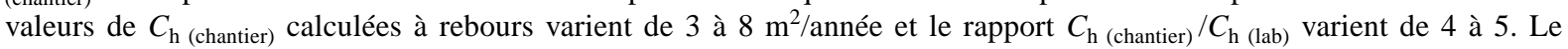
degré de consolidation estimé en partant des mesures de dissipation de la pression interstitielle concorde avec ceux obtenus par les mesures de tassement. Les réductions de teneur en eau d'après les mesures de chantier étaient aussi en bonne concordance avec les valeurs calculées par les tassement en consolidation. L'étude à l'échelle grandeur nature a confirmé que les amplitudes des tassements de consolidation augmentaient avec la diminution correspondante de l'espacement des PVD pour une période de temps donnée. Finalement, les résultats de l'étude grandeur nature a prouvé l'efficacité des PVD pour l'amélioration de l'argile de Bangkok.

Mots clés : argile molle, consolidation, drain vertical préfabriqué, préchargement, remblai d'essai.

[Traduit par la Rédaction]

Received 13 March 2001. Accepted 27 September 2001. Published on the NRC Research Press Web site at http://cgj.nrc.ca on 7 March 2002.

D.T. Bergado ${ }^{1}$ and A.S. Balasubramaniam. School of Civil Engineering, Asian Institute of Technology, P.O. Box 4, Klong Luang, Pathumthani 12120, Thailand.

R.J. Fannin. Department of Civil Engineering, University of British Columbia, Vancouver, BC V6T 1W5, Canada.

R.D. Holtz. Department of Civil Engineering, University of Washington, Seattle, WA, U.S.A.

${ }^{1}$ Corresponding author (e-mail: bergado@ait.ac.th). 


\section{Introduction}

To reduce the time for consolidation settlement of finegrained soils, prefabricated vertical drains (PVDs) can be used together with preloading to accelerate consolidation settlements. The PVD is a slender, synthetic drainage element comprised of a drainage core wrapped in a geotextile filter. Excess pore-water pressures, created by preloading, lead to preferential flow in the horizontal direction towards the PVD and along it vertically into the permeable drainage layers. Therefore, the PVD installation reduces the length of drainage paths and, consequently, shortens the time required to complete the consolidation process.

The Asian Institute of Technology (AIT) was engaged by the Airport Authority of Thailand to undertake the full-scale test of PVD alternatives for the new Bangkok International Airport (NBIA) project. Besides identifying the PVD types suitable for the project and verifying the actual field performance of the PVD, the full-scale study also examined the effects of using different PVD types and spacings. The fullscale study also confirms the effectiveness of the prediction and monitoring methods, such as the comparison of the degree of consolidation using pore-pressure measurement versus settlement measurement, comparison of the actual watercontent reduction with computed values, and comparison of the actual increase in shear strength with predicted values. Three full-scale test embankments (TS1-TS3) were constructed in stages on PVD-improved soft Bangkok clay at Nong Ngu Hao, Thailand, with PVD spacings of 1.5, 1.2, and $1.0 \mathrm{~m}$ in a square pattern (Table 1). All PVDs were installed to a depth of $12 \mathrm{~m}$. This study is a continuation of earlier publications (Bergado et al. 1996a, 1997) concerning the results and analyses of the full-scale study.

\section{Site and soil conditions}

The Bangkok subsoils, part of the larger Chao Phraya Plain, consist of alternate layers of sand, gravel, and clay. The underlying profile of the bedrock is still undetermined, but its level is known to be between 550 and $2000 \mathrm{~m}$ below the ground surface.

The test site is located approximately $30 \mathrm{~km}$ east of the city of Bangkok. The generalized soil profile and soil properties are shown in Fig. 1. The soil profile is relatively uniform, consisting of a $2 \mathrm{~m}$ thick weathered crust overlying very soft to soft clay approximately $10 \mathrm{~m}$ thick. Underlying the soft clay is a medium stiff clay layer about $4 \mathrm{~m}$ thick followed by a stiff clay layer extending down to $24 \mathrm{~m}$ depth which is in turn underlain by a layer of dense sand (standard penetration test (SPT) $N$ values of 30-50). The profiles of soil strength and compressibility parameters determined by laboratory and field tests are also shown in Fig. 1.

The natural water contents are reasonably uniform across the site and lie close to the liquid limit between depths of 2 and $16 \mathrm{~m}$. Most of the Atterberg limit values lie above the A line in the plasticity chart, confirming the high plasticity of the Bangkok clay. The groundwater table varies between 0.5 and $1.0 \mathrm{~m}$ below the ground surface.

\section{Selection and installation of prefabricated vertical drains (PVDs)}

Three factors are generally used to describe the effects on the ideal required discharge capacity of PVDs as calculated from the theory of consolidation (Bergado et al. 1996b). These factors are the influence of time, the influence of deformation, and the influence of filtration and clogging. Based on the results of the tests on PVD types, three PVD types were installed in the full-scale test embankments, namely, Flodrain in TS1, Castle Board drain in TS2, and Mebra drain in TS3, as tabulated in Table 1. The installation of PVDs is implemented by fixing the rig assembly at the desired location. Then, the anchor plate and mandrel with the PVD are driven to the desired depth. Subsequently, the mandrel is pulled out and the PVD remains anchored in place after cutting it $0.15 \mathrm{~m}$ above the surface of the sand blanket.

\section{Test embankment construction and stage loading}

In the area of the three test embankments, the original ground was cleared of grass roots and excavated to $0.3 \mathrm{~m}$ below mean sea level. Each test embankment is $40 \mathrm{~m} \times 40 \mathrm{~m}$ in plan dimensions with $3 H: 1 \mathrm{~V}$ side slopes and has a final height of $4.2 \mathrm{~m}$ (Fig. 2). A $1.0 \mathrm{~m}$ thick sand drainage blanket was laid on the excavated ground. The specifications for the sand blanket are given in Table 2. After installation of the PVD, the thickness of the sand drainage blanket was increased to $1.5 \mathrm{~m}$. Clayey sand was then used to raise the embankment to $4.2 \mathrm{~m}$ (i.e., $75 \mathrm{kPa}$ of surcharge) in stages. As shown in Fig. 3 for TS3, stage 1 loading was up to $18 \mathrm{kPa}$, stage 2 up to $45 \mathrm{kPa}$, stage 3 up to $54 \mathrm{kPa}$, and stage 4 up to $75 \mathrm{kPa}(4.2 \mathrm{~m}$ fill height). A berm $5 \mathrm{~m}$ wide and $1.5 \mathrm{~m}$ high was included when the surcharge increased from 45 to $54 \mathrm{kPa}$ (see Fig. 3). After the test embankment was preloaded to a certain height in the stage loading, a waiting period is needed in order for the underlying soft clay foundation to gain additional shear strength to achieve a minimum factor of safety of 1.3 against slope failure without machinery live load. The waiting period was 30 days for TS3 with a $45 \mathrm{kPa}$ surcharge, which was subsequently increased to $54 \mathrm{kPa}$. The design waiting period was 105 days for the embankment when the surcharge increased from 54 to $75 \mathrm{kPa}$. The factor of safety without considering the short-term condition of machinery live load $(5 \mathrm{kPa}$ live load) was generally in the range higher than 1.30, as shown in Fig. 3. The long-term factor of safety should be higher due to excess pore-pressure dissipation in the underlying clay layers.

A section of test embankment TS3 is shown in Fig. 4. The PVDs were installed to a depth of $12 \mathrm{~m}$ on a square pattern with $1.0 \mathrm{~m}$ spacing for TS3. The mandrel was rectangular in cross section with a thickness of $6 \mathrm{~mm}$ and outside dimensions of $150 \mathrm{~mm}$ by $45 \mathrm{~mm}$. Rectangular-shaped anchoring shoes with dimensions of $150 \mathrm{~mm}$ by $45 \mathrm{~mm}$ were utilized. Construction commenced in April 1994 and was completed 9 months later. The fill material was compacted to an average bulk unit weight of $18 \mathrm{kN} / \mathrm{m}^{3}$. The same dimensions and procedures were followed for the other test embankments, TS1 and TS2. 
Table 1. Types of PVD installed in the test embankments

\begin{tabular}{|c|c|c|c|}
\hline $\begin{array}{l}\text { Test } \\
\text { embankment }\end{array}$ & PVD type & $\begin{array}{l}\text { PVD } \\
\text { pattern }\end{array}$ & $\begin{array}{l}\text { PVD } \\
\text { spacing } \\
(\mathrm{m})\end{array}$ \\
\hline TS1 & Flodrain (FD4-EX) (studded core not fixed to filter) & Square & 1.5 \\
\hline $\mathrm{TS} 2$ & Castle Board (CS1) (grooved core fixed to filter) & Square & 1.2 \\
\hline TS3 & Mebra (MD-7007) (grooved core not fixed to filter) & Square & 1.0 \\
\hline
\end{tabular}

Fig. 1. General soil profile and properties.
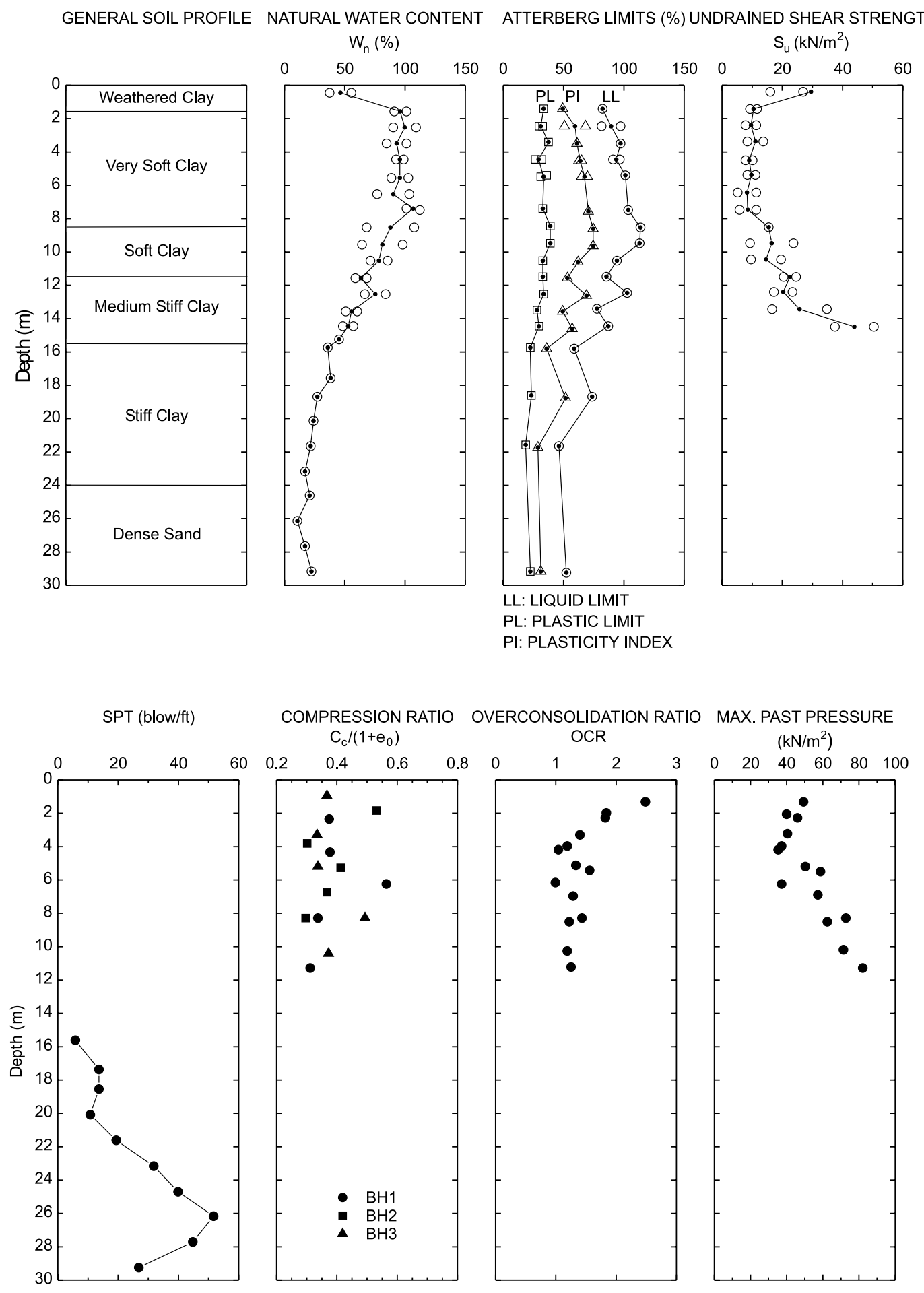
Fig. 2. Locations of boreholes and test embankments. BH1/B, soil boring sampling $76.2 \mathrm{~mm}-15 \mathrm{~m}$ before improvement; BH2/B, soil boring sampling $254 \mathrm{~mm}-11 \mathrm{~m}$ before improvement; BH3/B, soil boring sampling $76.2 \mathrm{~mm}-30 \mathrm{~m}$ before improvement; FV1/B$\mathrm{FV} 6 / \mathrm{B}$, field vane shear test before improvement. $\triangle$, piezocone test location.

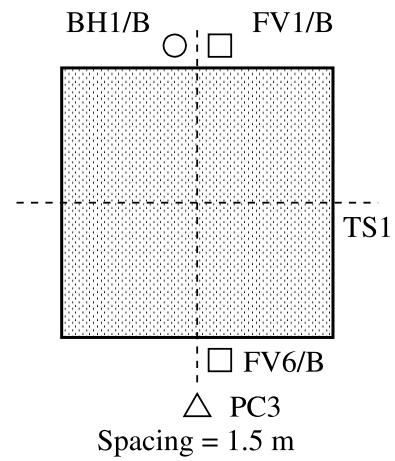

Table 2. Sand blanket specification (permeability $5 \times$ $10^{-2}$ to $5 \times 10^{-1} \mathrm{~mm} / \mathrm{s}$ ).

\begin{tabular}{cl}
\hline Sieve & Percent \\
No. & Finer \\
\hline 4 & $95-100$ \\
10 & $70-100$ \\
40 & $20-60$ \\
200 & $0-10$ \\
\hline
\end{tabular}

\section{Field performance of test embankment}

A field monitoring program was established to monitor surface and subsurface settlements, lateral movements, and excess pore pressures. In total, 20 settlement plates, two inclinometers, and 21 piezometers were installed in each test embankment. The surface and subsurface settlement gauges were installed near the center of the test embankment. The subsurface settlement gauges and the piezometers were installed at a $2 \mathrm{~m}$ vertical interval. The piezometers were installed at locations between the PVDs. The plan and section views showing the embankment instrumentation are given in Fig. 5.

Similar trends of settlements were observed in all three test embankments. A typical settlement characteristic is shown in Fig. 6 as taken from TS2 at the surface and at depth intervals of $2 \mathrm{~m}$ for subsurface settlements. Most of the compression occurred at depths of 2-8 m, corresponding to the very soft clay layer. The magnitude of surface settlements increased from TS1 to TS3, which corresponds to decreasing PVD spacing of $1.5,1.2$, and $1.0 \mathrm{~m}$ as shown in Fig. 7. Thus, the test embankment with the closest PVD spacing yielded the fastest settlement. A comparison of the surface settlement profiles was made for the three embankments, and all were observed to be quite symmetrical.

Two slope indicators, labeled I1 and I2, were installed in each embankment. Inclinometer I1 was located at the outer-
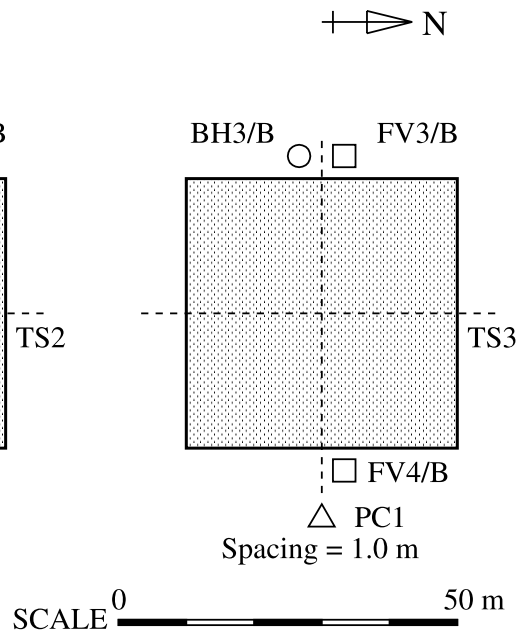

most edge of the embankment at a distance of $20 \mathrm{~m}$ from the center, and inclinometer I 2 was installed at the shoulder at maximum fill height. The results of inclinometer I 2 measurements in TS1 are shown in Fig. 8. Most of the lateral movements occurred at depths of $2-8 \mathrm{~m}$ in the very soft to soft clay layer.

The total pore pressures were measured by pneumatic, hydraulic, and open-standpipe piezometers. The readings were corrected for settlements at the piezometer tips. Figure 9 shows the data measured by pneumatic piezometers in TS1. The pneumatic piezometers PP2, PPS4, PPS6, and PP8 were installed at depths of 2, 4, 6, and $8 \mathrm{~m}$, respectively. Although the rate was slow and delayed, there was a definite dissipation of excess pore pressures.

\section{Estimation of total settlements}

Terzaghi's one-dimensional (1D) consolidation theory was used to estimate the $1 \mathrm{D}$ primary consolidation settlements. In Fig. 7, the calculated total settlements using 1D consolidation theory for TS1, TS2, and TS3 are shown as solid lines in the time-settlement plots which are similar to the corresponding measured values plotted as "dotted" lines. The data used in the 1D settlement calculation of test embankment TS3 are tabulated in Table 3.

\section{Pore-pressure profiles}

The measured pore-pressure profile for TS3 indicated that the excess pore pressure has fully dissipated. Figure 10 illustrates the measured and assumed pore-pressure profiles with depth for TS3. Line ABC in Fig. 10 represents the dummy pore pressures, and line DEF represents the theoretical pore pressures immediately after loading with a $75 \mathrm{kPa}$ surcharge. The dummy pore pressures were obtained at the unloaded part of the site and were located away from the influences of the test embankments. The dummy readings represent the initial pore-pressure conditions before preloading which indicated the pore-pressure drawdown due to excessive withdrawal of groundwater from the underlying aquifers. In 
Fig. 3. Summary of stability and settlement analyses for embankment TS3 (with $1.0 \mathrm{~m}$ drain spacing). $\Delta \sigma_{\mathrm{v}}^{\prime}$, increase in effective stress at calculated time; $q_{\mathrm{c}}$, embankment load at calculated time; $u_{\mathrm{p}}$, excess pore pressure just after adding the additional load, including the remaining pore pressure from the previous stage; $S_{\mathrm{c}}$, consolidation settlement at calculated time; $S_{\mathrm{cf}}$, final consolidation settlement at $72 \mathrm{kPa}$ load $=1.30 \mathrm{~m} ; S_{\mathrm{u}}$, developed undrained shear strength; $S_{\mathrm{u} 0}$, initial undrained shear strength.

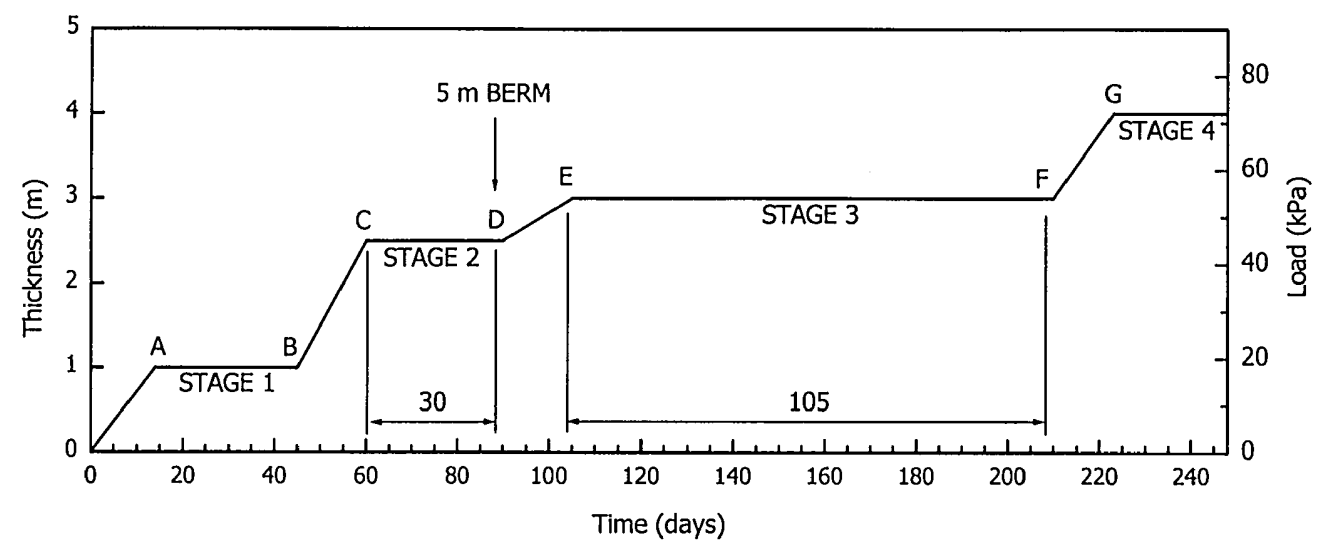

SUMMARY OF THE STABILITY ANALYSIS

\begin{tabular}{|c|c|c|c|c|c|}
\hline \multirow{2}{*}{ POINT } & THICKNESS & \multirow{2}{*}{ LOAD } & \multirow{2}{*}{ DURATION } & \multicolumn{2}{|c|}{ FACTOR OF SAFETY } \\
\cline { 5 - 6 } & $(\mathbf{m})$ & $\mathbf{( k P a )}$ & (Days) & $\begin{array}{c}\text { with 5 kPa } \\
\text { Machinery Live Load }\end{array}$ & $\begin{array}{c}\text { without } \\
\text { Load }\end{array}$ \\
\hline \hline C & 2.5 & 45 & & 1.18 & 1.30 \\
\hline D & 2.5 & 45 & 30 & 1.33 & 1.48 \\
\hline E & 3.0 & 54 & & 1.23 & 1.34 \\
\hline F & 3.0 & 54 & 105 & 1.54 & 1.65 \\
\hline G & 4.0 & 75 & & 1.26 & 1.34 \\
\hline
\end{tabular}

Calculated Strength Gain and Settlement at the End of Each Loading Stage

\begin{tabular}{|c|c|c|c|c|c|c|}
\hline POINT & $\begin{array}{c}\Delta \sigma^{\prime}{ }_{\mathbf{v}} \\
(\mathbf{k P a})\end{array}$ & $\begin{array}{c}\mathbf{R S}_{\mathbf{u}} \\
\left(\mathbf{S}_{\mathbf{u}} / \mathbf{S}_{\mathbf{u} \mathbf{0}}\right)\end{array}$ & $\Delta \sigma^{\prime}{ }_{\mathbf{v}} / \Delta \mathbf{q}_{\mathbf{c}}$ & $\Delta \sigma^{\prime}{ }_{\mathrm{v}} / \Delta \mathbf{u}_{\mathbf{p}}$ & $\begin{array}{c}\mathbf{S}_{\mathbf{c}} \\
(\mathbf{m})\end{array}$ & $\mathbf{S}_{\mathbf{c}} / \mathbf{S}_{\mathbf{c f}}$ \\
\hline \hline $\mathrm{D}$ & 11.4 & 1.07 & 0.25 & 0.25 & 0.22 & 0.17 \\
\hline $\mathrm{F}$ & 35.1 & 1.42 & 0.65 & 0.83 & 0.65 & 0.50 \\
\hline
\end{tabular}

Fig. 4. Test embankment TS3 (4.2 $\mathrm{m}$ height).
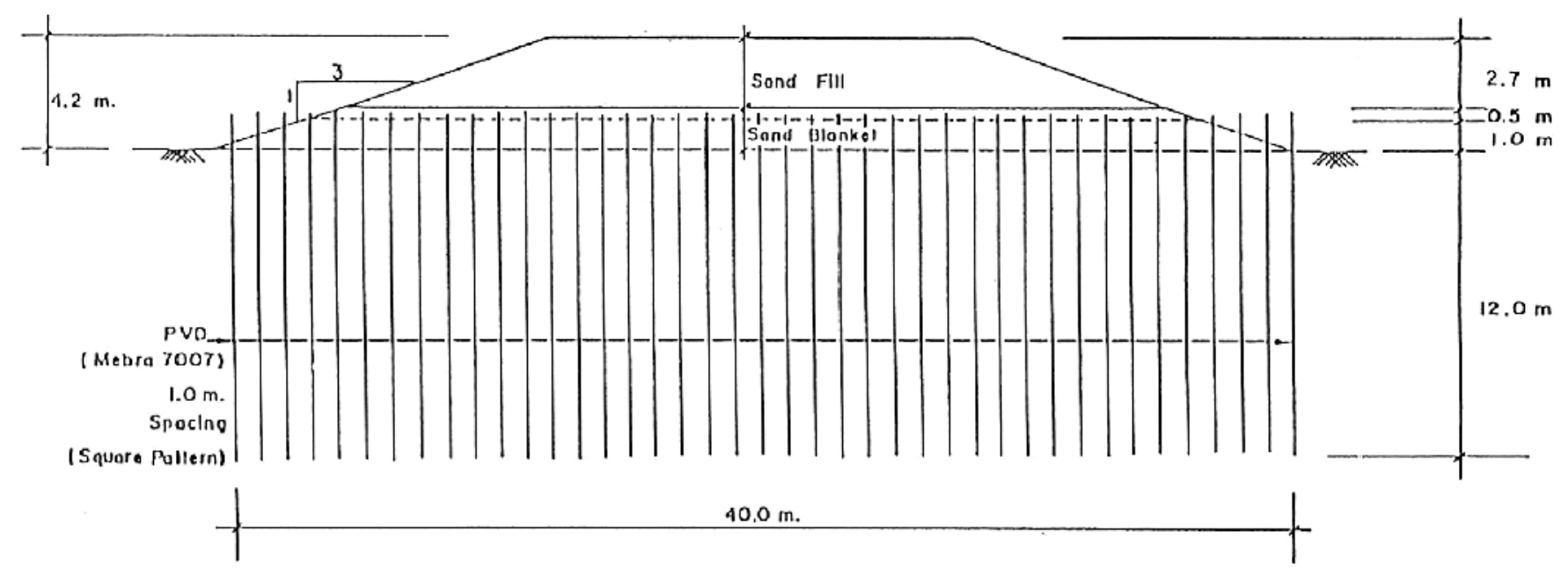
Fig. 5. Plan and section views of instrumentation. MSL, mean sea level.

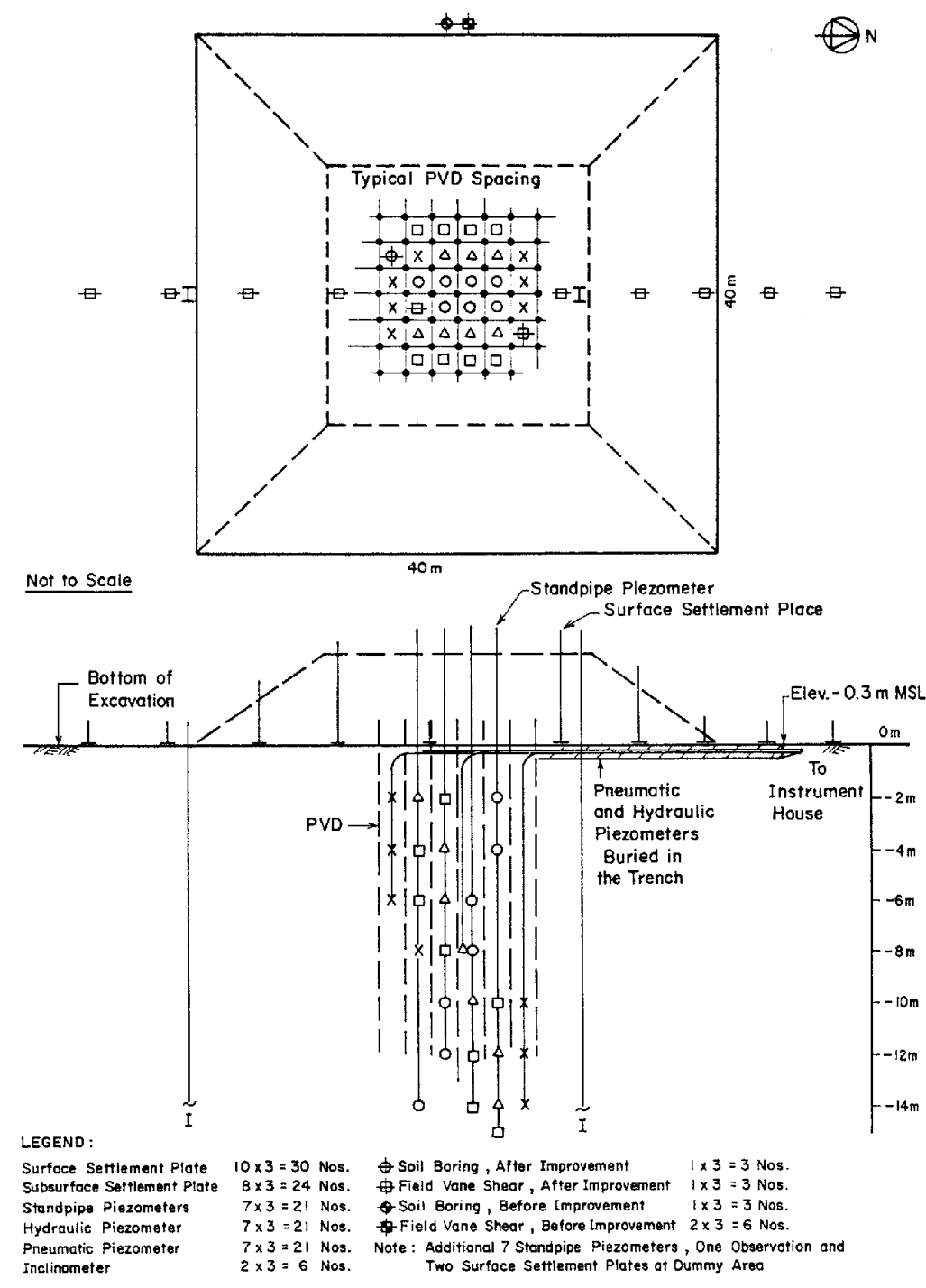

Fig. 10, the theoretical total pore-pressure profile immediately after $75 \mathrm{kPa}$ loading is indicated by line DEF. The measured pore pressures after 1 year of preloading in June 1995 are indicated by line AGHIJ. Line MNPQ represents the average total pore-pressure readings in February 1996. In comparison with the dummy readings (line $\mathrm{ABC}$ ) which represented the initial piezometric pressures, it can be observed that there is recharge from 8 to $12 \mathrm{~m}$ depth. Thus, the recharge extends to the PVD zone down to $12 \mathrm{~m}$ depth. The hydrostatic pore pressure without any drawdown is indicated by line AKL. The measured excess pore-pressure profile as of February 1996 corresponds to line MNPQ, which indicates full dissipation of excess pore pressures.

\section{Consolidation with PVDs}

Barron (1948) first presented the solution to the problem of consolidation of a soil cylinder containing a central sand drain. Hansbo (1979) recommended modifications to the solution which dealt mainly with simplifying assumptions due to the physical dimensions, characteristics of the PVD, and the effects of PVD installation. The compressibility and flow parameters have been discussed by Bergado et al. (1996a) and include the equivalent diameter of a unit PVD influence zone, $D_{\mathrm{e}}$; the equivalent diameter of the PVD, $d_{\mathrm{w}}$; the horizontal permeability in the undisturbed soil, $k_{\mathrm{h}}$; the horizontal permeability of the smeared zone, $k_{\mathrm{s}}$; the diameter of the smeared zone, $d_{\mathrm{s}}$; the distance from the drainage end of the PVD, $z$; the length of the PVD for one-way drainage and half of the length of the PVD for two-way drainage, $L$; and the discharge capacity of the PVD at a hydraulic gradient of $1, q_{\mathrm{w}}$.

It has been shown from back-analysis of an instrumented test embankment on a similar clay in Canada (Crawford et al. 1992) that the calculated rates of consolidation are not sensitive to common methods of establishing $D_{\mathrm{e}}$, nor to the value of $q_{\mathrm{w}}$, and that the most significant design parameter is the coefficient of consolidation in radial drainage, $C_{\mathrm{h}}$. In this study, on the other hand, the aforementioned compressibility parameters played a vital role in the successful prediction of consolidation settlements. The calculated surface settlements using 1D consolidation with radial drainage (Hansbo 1979) are also plotted in Fig. 7. The predictions agreed with the measured values. 
Fig. 6. Settlement of layers of increasing thickness from the ground surface (embankment TS2).

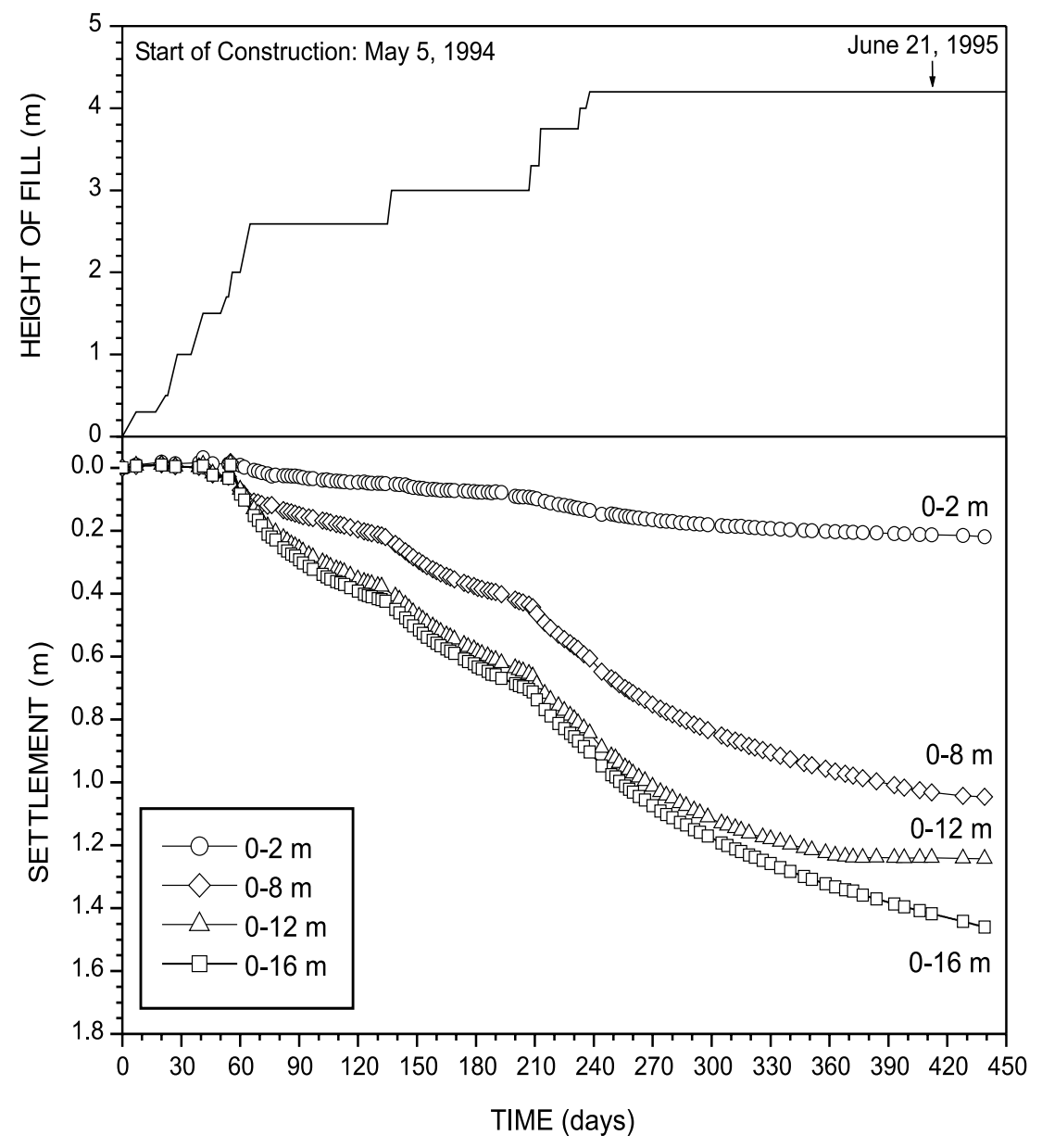

\section{Degree of consolidation}

The degree of consolidation of the clay layers below the test embankments was calculated both from pore-pressure dissipation and from the settlements of the test embankments. The pore-pressure dissipation with depth is presented in Fig. 10. If the compression ratio is assumed to be constant, then the degree of consolidation can be obtained from the measured pore pressures. The corresponding values of the degree of consolidation can also be obtained from the measured settlements. Figure 11 compares the calculated degrees of consolidation. The degrees of consolidation obtained from settlement measurements were confirmed by the corresponding values from excess porepressure measurements.

The degree of consolidation obtained from pore pressures $\left(U_{\mathrm{p}}\right)$ is consistently less than that from settlements $\left(U_{\mathrm{s}}\right)$. A similar observation was reported earlier by Holtz and Broms (1972). The delay in calculated degree of consolidation from pore-pressure observations obtained here is in accordance with Mikasa consolidation theory (Mikasa 1965). During the compression and rearrangement of the soil structure, the excess pore pressures were maintained at higher levels similar to the observations of Holtz and Broms and Crawford et al. (1992).

\section{Secondary compression}

Further insight into the settlement characteristics can be obtained by plotting the rate of settlement versus the inverse of time (Fig. 12). Over a period of approximately 20 months, the rate of settlement reduced very quickly with time in an exponential manner. Beyond a period of 20 months, however, the rate seemed to reach an asymptotic decay with a slope of $25 H: 1 \mathrm{~V}$ which could be attributed to the secondary compression. Assuming that the secondary compression is a linear function of the logarithm of time, then the slope of this line is the product of the soil thickness, $H$, and the secondary compression ratio, $C_{\alpha}$. With $H=14 \mathrm{~m}, C_{\alpha}$ can be obtained as 0.018 . This value of $C_{\alpha}$ is within the range of $0.01-0.02$ as suggested by Mesri (1973) for marine clays. The $C_{\alpha}$ values for soft Bangkok clay range from 0.011 to 0.021 (Kulatilake 1978; Ong 1983), with $C_{\alpha} / C_{\mathrm{c}}$ values of 0.04-0.05 (Cox 1981; Wongprasert 1991), where $C_{\mathrm{c}}$ is the compression index.

The consolidation settlement - logarithm of time plots were prepared by Bergado et al. (1997) to estimate the secondary consolidation parameter, $C_{\alpha}$. The final linear portion is almost achieved and, based on the slope of this curve of $25 H: 1 \mathrm{~V}$ (or $C_{\alpha}=0.018$ ), as obtained from the rate of settlement - inverse time plot, the observations seem to 
Fig. 7. Comparison of measured total settlement and calculated 1D settlement (embankments TS1, TS2, and TS3).

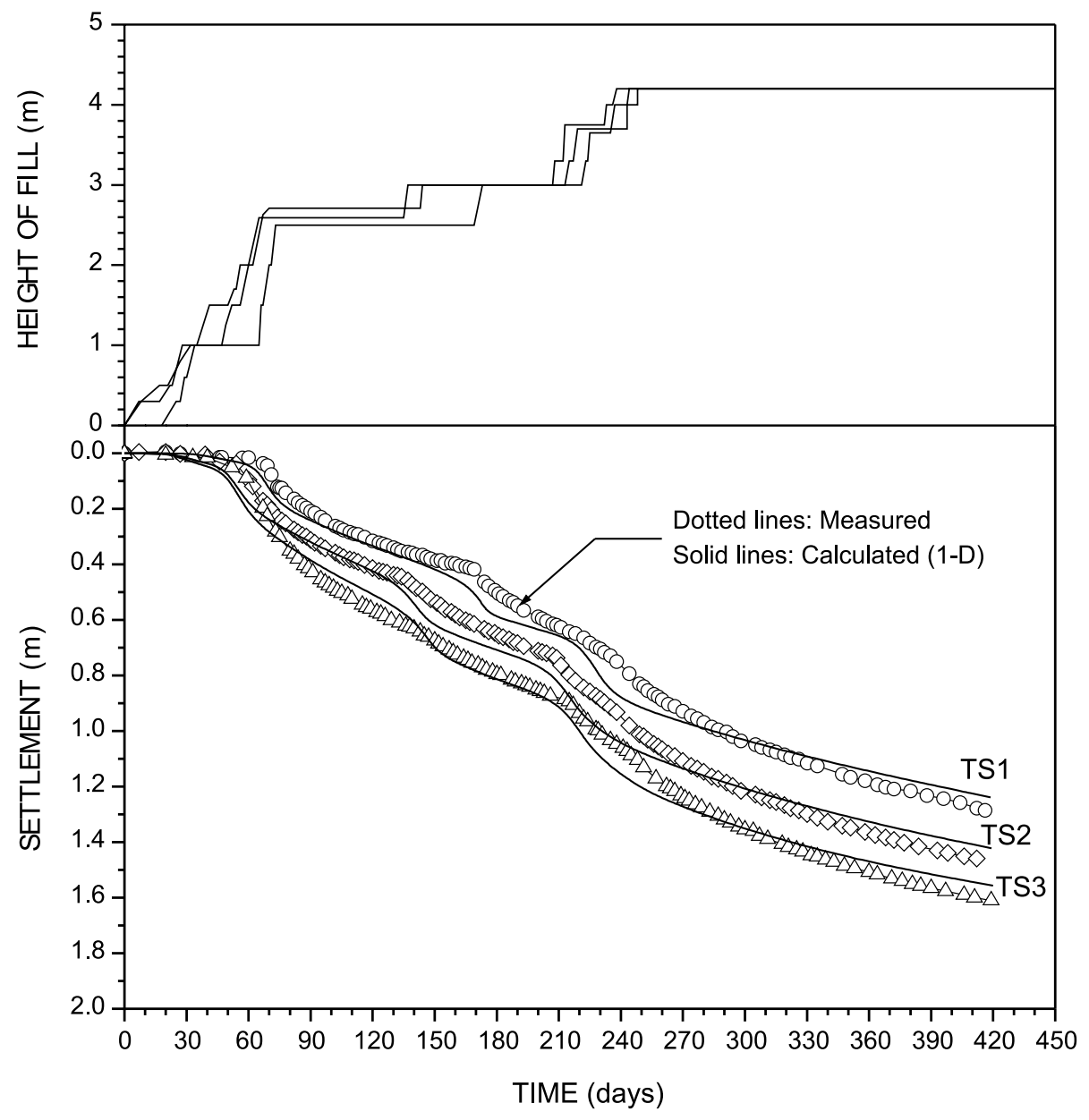

approach a linear portion (Bergado et al. 1997). As plotted in line MNPQ in Fig. 10, the excess pore pressures have fully dissipated.

\section{Reduction of water content}

Figure 13 illustrates the reduction of water content with depth for TS3 in February 1996 after 660 days of preloading compared with the mean values of the initial water contents measured in February 1994. The back-calculated values of water content from settlements in March 1996 are also plotted in Fig. 13 for TS3 and are in agreement with the measured water content data.

Under the test embankment, a substantial reduction in water content is noted. For the very soft clay from 2 to $6 \mathrm{~m}$ depth, the reduction in water content is consistent, i.e., higher reduction corresponding to smaller PVD spacing in TS3. The reduction in water content in TS3 is more than $20 \%$.

\section{Increase of shear strength}

The increase in undrained shear strength, $S_{\mathrm{u}}$, was predicted by the SHANSEP technique (Ladd 1991) as follows:

$$
\left(\frac{S_{\mathrm{u}}}{\bar{\sigma}_{\mathrm{vo}}}\right)_{\mathrm{OC}}=\left(\frac{S_{\mathrm{u}}}{\bar{\sigma}_{\mathrm{vo}}}\right)_{\mathrm{NC}} \mathrm{OCR}^{m}
$$

where OCR is the overconsolidation ratio; $\bar{\sigma}_{\mathrm{vo}}$ is the effective overburden pressure; and $\mathrm{NC}$ and $\mathrm{OC}$ denote normally consolidated and overconsolidated, respectively. For soft Bangkok clay,

[2] $\left(\frac{S_{\mathrm{u}}}{\bar{\sigma}_{\mathrm{vo}}}\right)_{\mathrm{NC}}=0.22$ and $m=0.8$

Therefore,

$$
\left(\frac{S_{\mathrm{u}}}{\overline{\bar{\sigma}}_{\mathrm{vo}}}\right)_{\mathrm{OC}}=0.22(\mathrm{OCR})^{0.8}
$$

The predicted increases in undrained shear strengths are indicated by solid lines in Fig. 14. The corrected undrained shear strengths measured by field vane shear tests in March 1996 are also plotted for comparison. As shown in Fig. 14, there is excellent agreement between the measured and predicted data with regards to the increase in undrained shear strength due to preconsolidation and drainage. The SHANSEP technique was also used in the calculation of the increase in undrained shear strength for the stability analyses as demonstrated in Fig. 3. 
Fig. 8. Lateral deformation with depth (embankment TS1, inclinometer I2). Dates are given as day/month/year.

LATERAL DEFORMATION (mm)

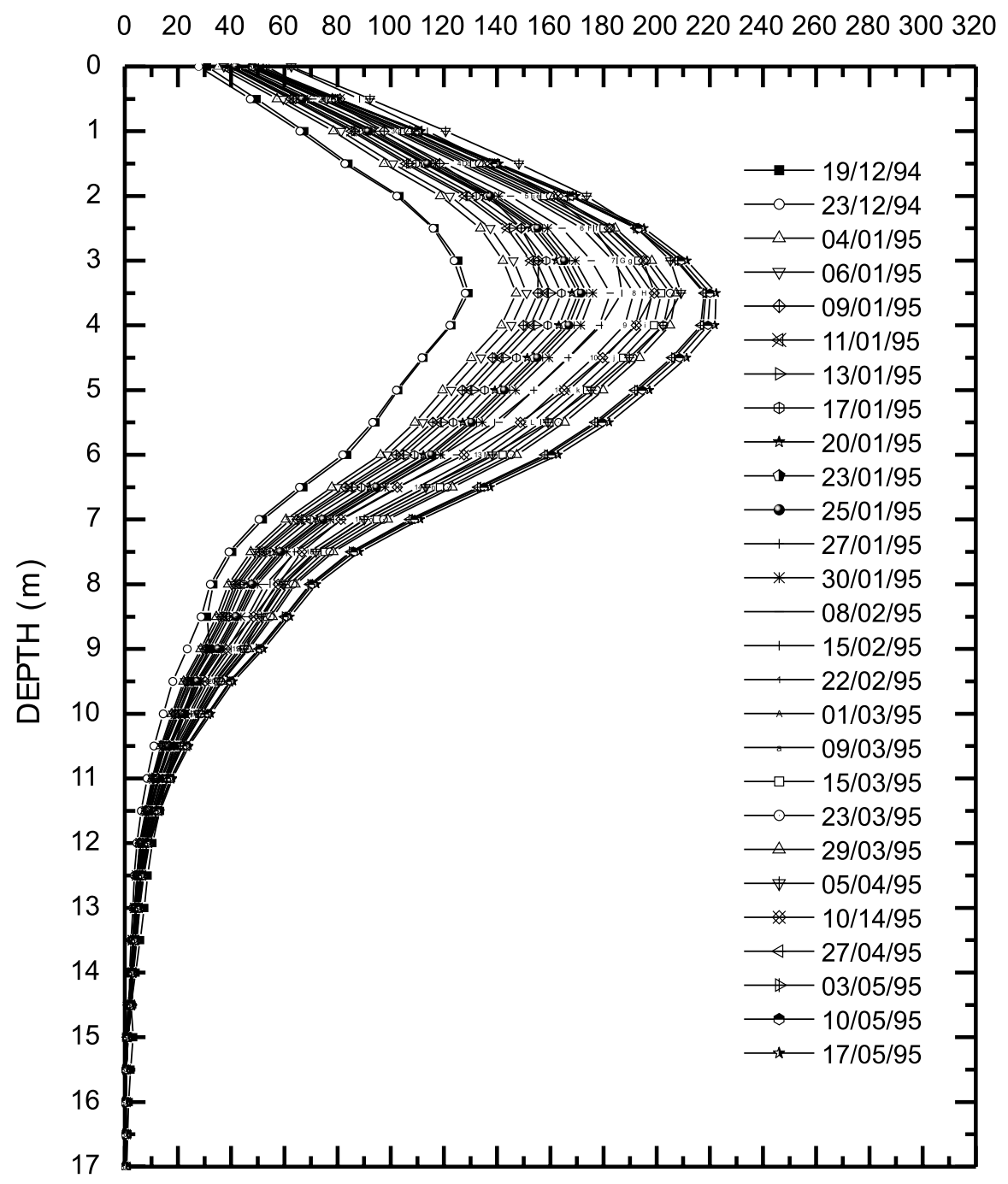

\section{Back-calculation of $C_{h}$ values from pore- pressure measurements}

From the equation of Hansbo (1979) for the consolidation of PVDs, the following equation can be derived:

$$
1-\frac{\Delta u_{t}}{\Delta u_{0}}=1-\exp (-\alpha t)
$$

and

$$
\text { [5] } \alpha=\frac{8 C_{\mathrm{h}}}{D_{\mathrm{e}} F}
$$

where $\Delta u_{0}$ is the excess pore pressure at a reference time of $t=0 ; \Delta u_{t}$ is the excess pore pressure at time $t ; D_{\mathrm{e}}$ is the effective diameter of a unit cell of drain; and $F$ is a resistance factor for the effects of spacing, smear, and well resistance.

From eq. [4] we can get

[6] $\ln \frac{\Delta u_{0}}{\Delta u_{t}}=\alpha t$
Therefore, the values of $\alpha$ can be obtained as the slope of the plot $\ln \left(\Delta u_{0} / \Delta u_{t}\right)$ versus $t$. Having the values of $\alpha$, the coefficient of horizontal consolidation $C_{\mathrm{h}}$ can be calculated from eq. [5].

The back-calculated $C_{\mathrm{h}}$ values from the hydraulic piezometer data are plotted in Fig. 15 against the increase in effective stress. The $C_{\mathrm{h}}$ values decreased consistently with the increase in effective stress (with the progress of consolidation) for all depths. The weathered crust ( $2 \mathrm{~m}$ depth) has the highest $C_{\mathrm{h}}$ value, and the weakest soil at $6 \mathrm{~m}$ depth has the lowest $C_{\mathrm{h}}$ value. The $C_{\mathrm{h}}$ values at 4 and $10 \mathrm{~m}$ are higher than that at $6 \mathrm{~m}$ depth.

\section{Back-calculation of $\mathbf{C}_{h}$ values from settlement measurements}

Equation [4] can be written in terms of settlement as follows:

[7] $\frac{S_{t}}{S_{f}}=1-\exp (-\alpha t)$ 
Fig. 9. Pore pressures from pneumatic piezometers corrected for settlements (embankment TS1).

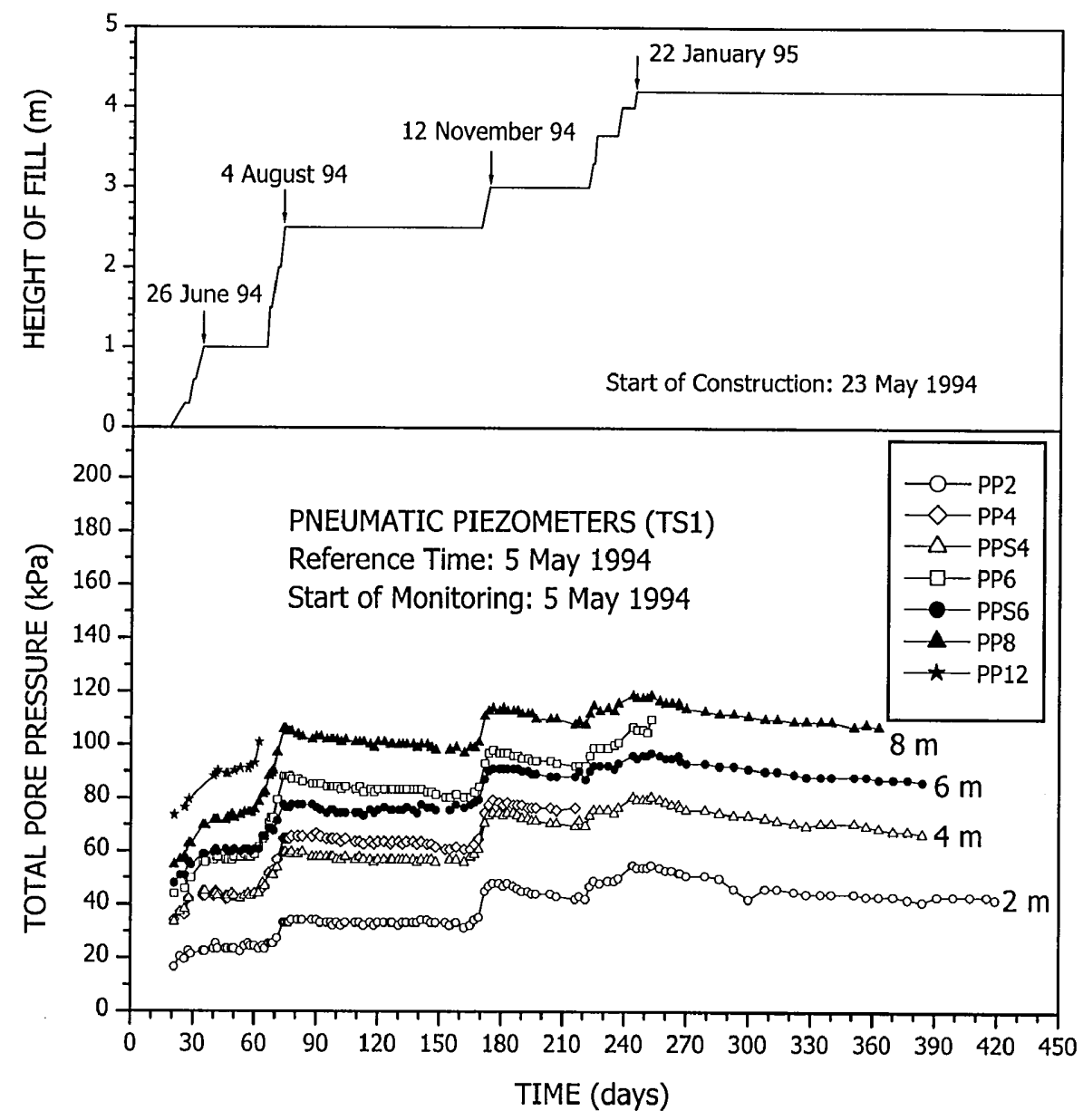

Table 3. Compression ratio (CR), recompression ratio $(\mathrm{RR})$, and preconsolidation stress $\left(\sigma_{\mathrm{p}}^{\prime}\right)$ values used in 1D consolidation settlement analysis.

\begin{tabular}{ccccl}
\hline $\begin{array}{l}\text { Depth } \\
(\mathrm{m})\end{array}$ & $\mathrm{CR}$ & $\mathrm{RR}$ & $\begin{array}{l}\sigma_{\mathrm{p}}^{\prime} \\
(\mathrm{kPa})\end{array}$ & $\begin{array}{l}\text { Settlement } \\
(\mathrm{m})\end{array}$ \\
\hline $0-2$ & 0.30 & 0.06 & 60 & 0.22 \\
$2-4$ & 0.40 & 0.08 & 55 & 0.29 \\
$4-6$ & 0.50 & 0.10 & 50 & 0.40 \\
$6-8$ & 0.50 & 0.10 & 55 & 0.35 \\
$8-10$ & 0.45 & 0.09 & 75 & 0.21 \\
$10-12$ & 0.35 & 0.07 & 90 & 0.12 \\
$12-16$ & 0.30 & 0.06 & 124 & 0.15 \\
\hline
\end{tabular}

where $S_{t}$ is the consolidation settlement, and $S_{\mathrm{f}}$ is the final settlement. From eq. [7], the following equation can be derived:

[8] $\ln \frac{S_{\mathrm{f}}}{S_{\mathrm{f}}-S_{\mathrm{t}}}=\alpha t$

Therefore, the $C_{\mathrm{h}}$ values can be obtained from the slope, $\alpha$, of the $\ln \left[S_{\mathrm{f}} /\left(S_{\mathrm{f}}-S_{t}\right)\right]$ versus $t$ plot. The average values of $C_{\mathrm{h}}$ (at $12 \mathrm{~m}$ depth in the PVD-improved zone) calculated from embankment TS3 were obtained as a function of the increased effective stress. The average $C_{\mathrm{h}}$ value at the end of construction is about $3 \mathrm{~m}^{2} /$ year and tends to reduce to less
Fig. 10. Pore-pressure profiles for settlement computations (embankment TS3).

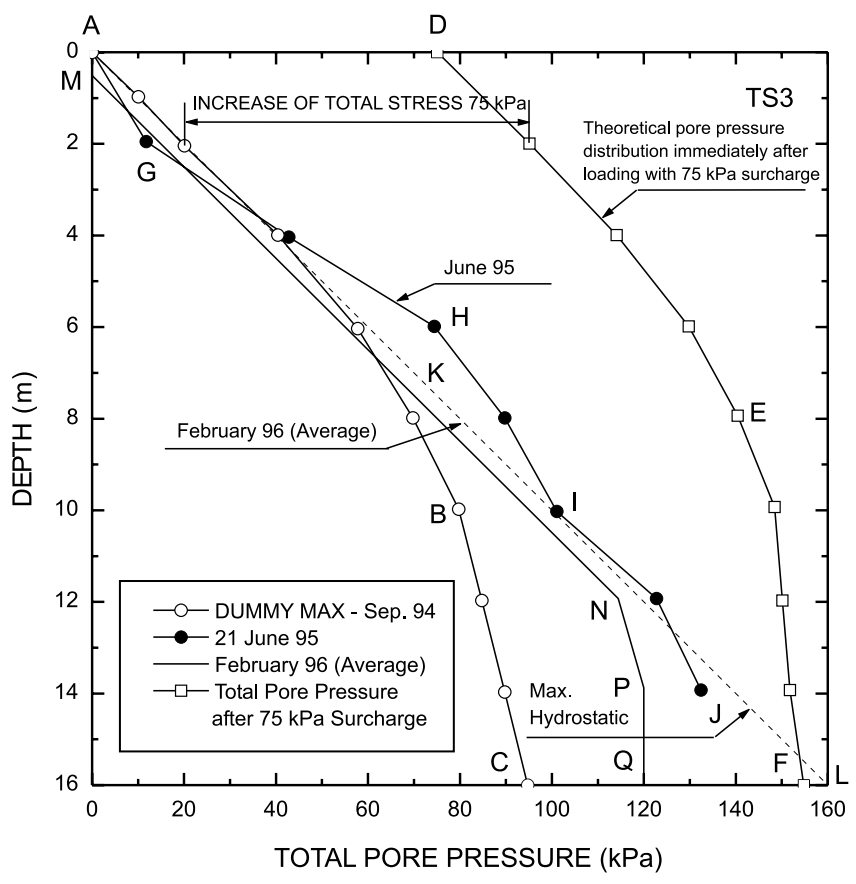


Fig. 11. Comparison of degrees of consolidation from settlement $\left(U_{\mathrm{s}}\right)$ and pore pressures $\left(U_{\mathrm{p}}\right)$.

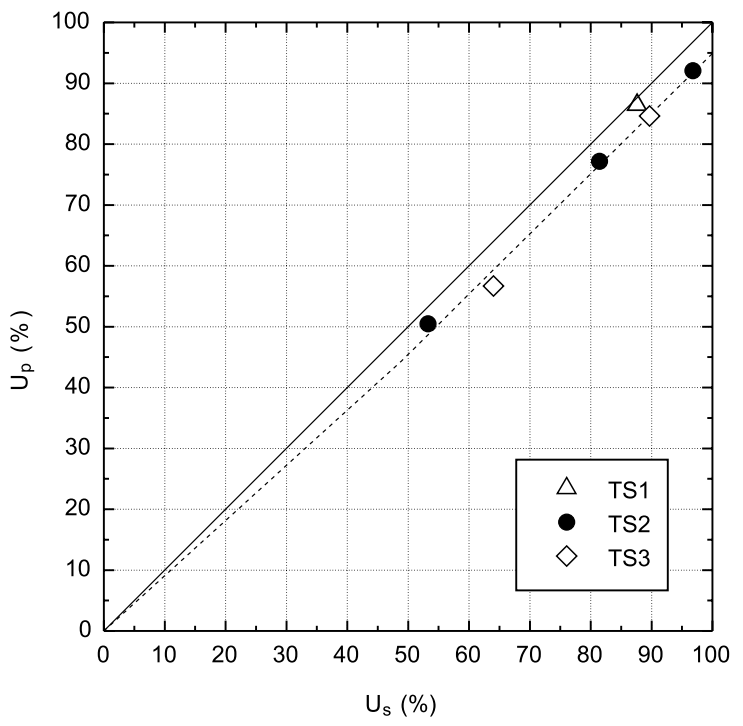

Fig. 12. Rate of settlement versus inverse time plot for embankment TS3.

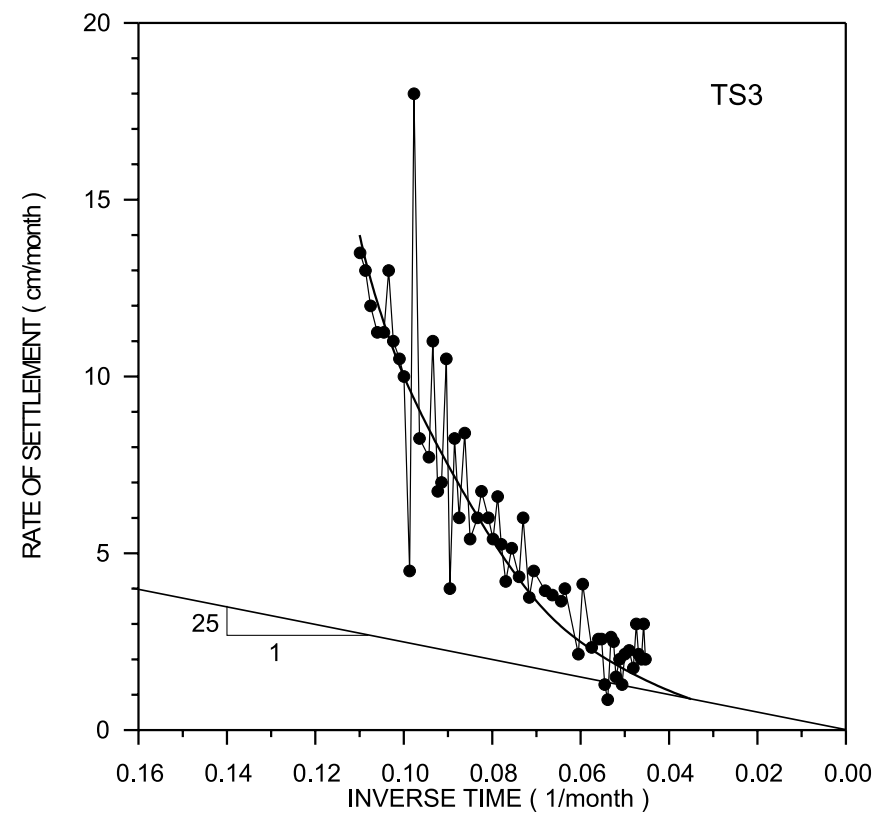

than $0.5 \mathrm{~m}^{2} /$ year at the full increase of effective stress of $75 \mathrm{kPa}$. Thus, the $C_{\mathrm{h}}$ values obtained from settlement are slightly higher than those estimated from pore pressure back-calculations. The back-calculated $C_{\mathrm{h}(\text { field })}$ values using the method of Asaoka (1978) range from 3 to $8 \mathrm{~m}^{2} /$ year as presented by Bergado et al. (1996a). The corresponding laboratory values range from 0.5 to $1.5 \mathrm{~m}^{2} /$ year. Bergado et al. (1992) obtained values of $C_{\mathrm{h}(\text { field })} / C_{\mathrm{h}(\text { lab })}$ ranging from 4 to 5 .

\section{Conclusions}

The performance of a full-scale test embankment constructed on soft Bangkok clay with prefabricated vertical drains (PVD) at the site of the new Bangkok International
Fig. 13. Back-calculated water contents from settlements for embankment TS3.

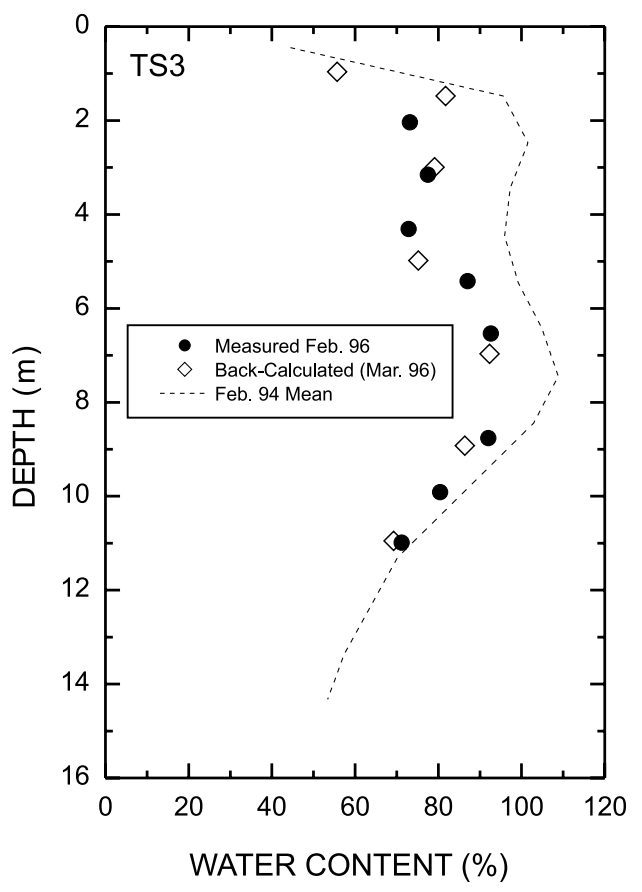

Fig. 14. Field vane shear strength measured below embankment TS3.

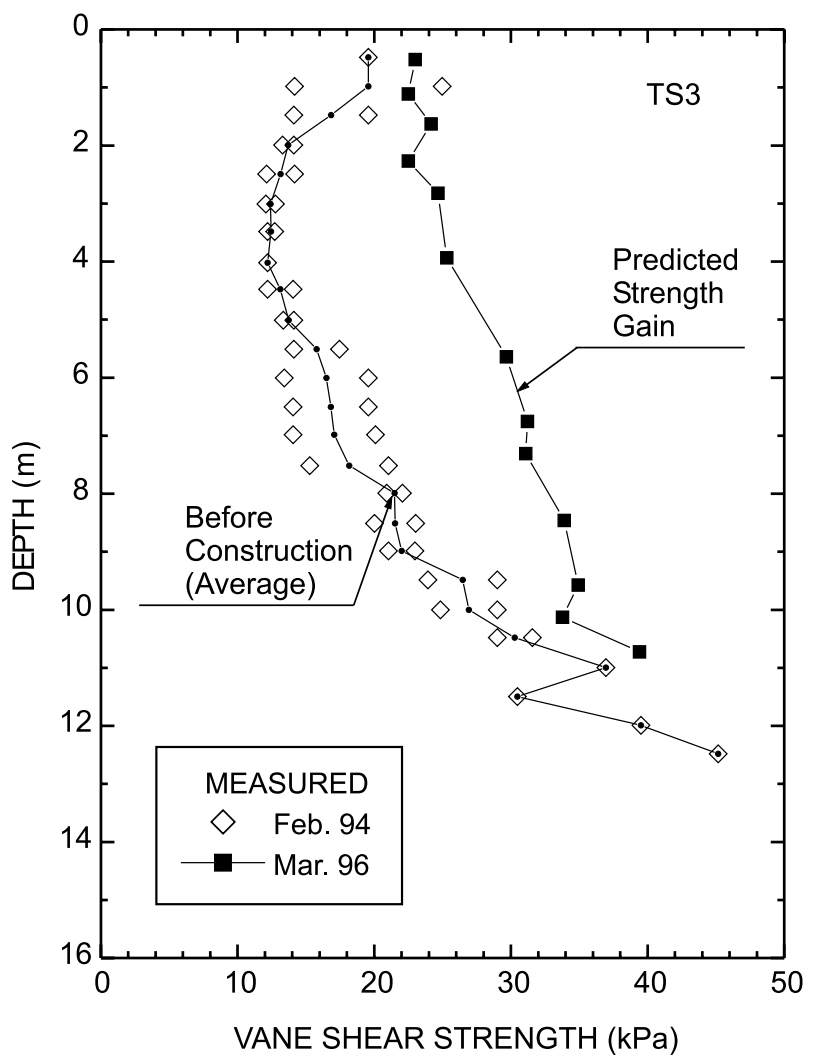

Airport (NBIA) project are presented in this paper. From the field measurements and the subsequent analyses, the following conclusions are made: 
Fig. 15. Plot of back-calculated $C_{\mathrm{h}}$ values from the pore-pressure data versus effective stress.

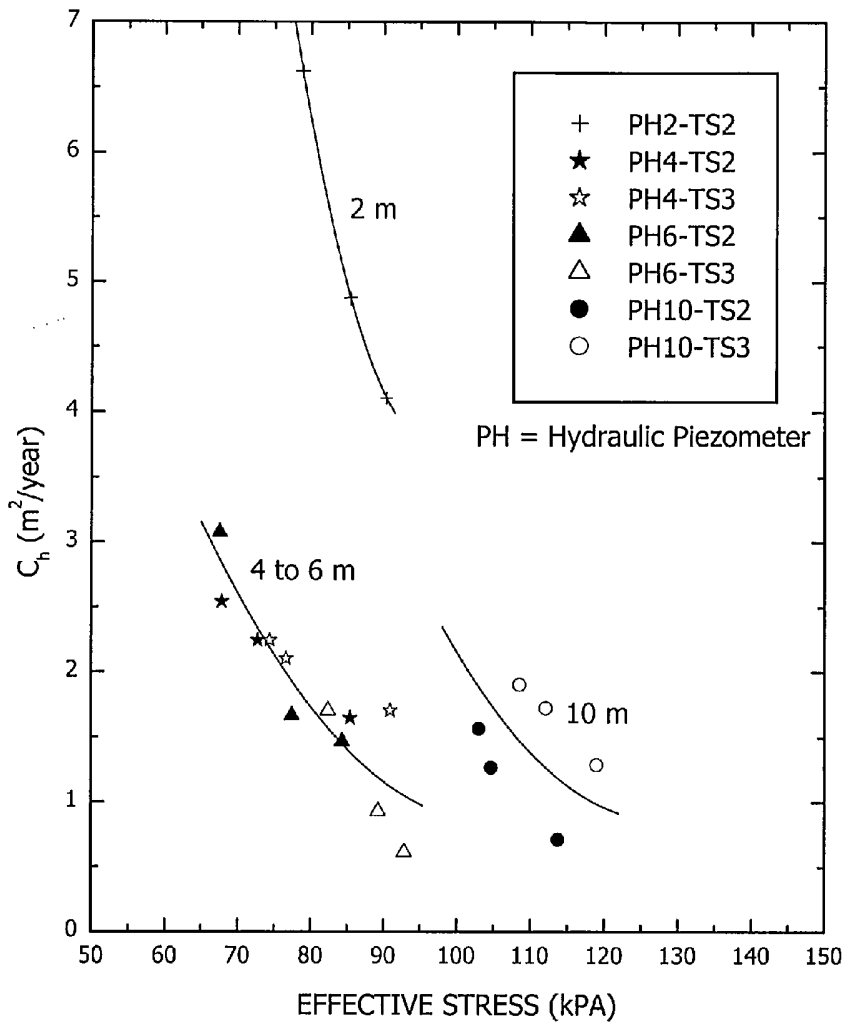

(1) For test embankments TS1, TS2, and TS3, the magnitudes of consolidation settlements correspondingly increased with a decrease in PVD spacing at a particular time period.

(2) The degree of consolidation obtained from porepressure measurements was lower than the corresponding values obtained from settlement measurements.

(3) The water-content reductions from the field measurements are in agreement with the values computed from the consolidation settlements.

(4) There is excellent agreement between the measured and predicted increase in undrained shear strengths. The prediction employed the SHANSEP technique.

(5) The back-calculated $C_{\mathrm{h}}$ values reduce substantially with an increase in the degree of consolidation, and the weakest soil layer at $6 \mathrm{~m}$ depth has a lower $C_{\mathrm{h}}$ value than those at 4 and $10 \mathrm{~m}$ depth. The values of $C_{\mathrm{h}(\text { field })}$ range from 3 to $8 \mathrm{~m}^{2} /$ year, and the ratio of $C_{\mathrm{h} \text { (field) }}$ to $C_{\mathrm{h}(\text { lab) }}$ ranges from 4 to 5 .

(6) The rate of settlement versus time plots indicate a value of 0.018 for the secondary compression ratio, $C_{\alpha}$, which lies within the range of values for marine clays.

(7) The results of the full-scale study demonstrate the effectiveness of PVDs in the improvement of soft Bangkok clay.

\section{References}

Asaoka, A. 1978. Observational procedure for settlement prediction. Soils and Foundations, 18(4): 87-101.

Barron, R.A. 1948. Consolidation of fine-grained soils by drain wells. Transactions of the American Society of Civil Engineers, 124: 718-742.

Bergado, D.T., Enriquez, A.S., Sampaco, C.L., Alfaro, M.C., and Balasubramaniam, A.S. 1992. Inverse analysis of geotechnical parameters on improved soft Bangkok clay. Journal of Geotechnical Engineering, ASCE, 118(7): 1012-1030.

Bergado, D.T., Long, P.V., and Balasubramaniam, A.S. $1996 a$. Compressibility and flow parameters from PVD improved soft Bangkok clay. Geotechnical Engineering Journal, 27(1): 1-20.

Bergado, D.T., Mannivannan, R., and Balasubramaniam, A.S. 1996b. Proposed criteria for discharge capacity of prefabricated vertical drains. Geotextiles and Geomembranes Journal, 14: 481-505.

Bergado, D.T., Balasubramaniam, A.S., Fannin, R.J., Anderson, L.R., and Holtz, R.D. 1997. Full scale field test of prefabricated vertical drain (PVD) on soft Bangkok clay and subsiding environment. In Ground improvement, ground reinforcement and ground treatment developments 1987-1997 (Geologan'97). Edited by V.R. Schaefer. American Society of Civil Engineers, Geotechnical Special Publication 69, pp. 372-393.

Cox, J.B. 1981. The settlement of a $55 \mathrm{~km}$ long highway on soft Bangkok clay. In Proceedings of the 10th International Conference on Soil Mechanics and Foundation Engineering, Stockholm, Sweden. Vol. 1, pp. 101-104.

Crawford, C.B., Fannin, R.J., deBoer, L.J., and Kern, C.B. 1992. Experiences with prefabricated vertical (wick) drains at Vernon, B.C. Canadian Geotechnical Journal, 29: 67-79.

Hansbo, S. 1979. Consolidation of clay by band-shaped prefabricated drains. Ground Engineering, 12(5): 16-25.

Holtz, R.D., and Broms, B.B. 1972. Long term loading tests at Ska-Edeby, Sweden. In Proceedings of the Specialty Conference on the Performance of Earth and Earth-Supported Structures, Lafayette, Ind., Vol. 1, pp. 435-464.

Kulatilake, P.H.S.W. 1978. Secondary compression study related to Bangkok subsidence. M.Eng. thesis 1291, Asian Institute of Technology, Bangkok, Thailand.

Ladd, C.C. 1991. Stability evaluation during staged construction. Journal of Geotechnical Engineering, ASCE, 117(4): 540-615.

Mesri, G. 1973. Coefficient of secondary consolidation. Journal of the Soil Mechanics and Foundation Engineering Division, ASCE, 99(SM1): 122-137.

Mikasa, M. 1965. The consolidation of soft clay. In Civil Engineering in Japan. Japan Society of Civil Engineers, Tokyo, pp. 21-26.

Ong, B. 1983. Behavior of secondary settlement under preconsolidation. M.Eng. thesis GT-82-19, Asian Institute of Technology, Bangkok, Thailand.

Wongprasert, M. 1991. Settlement analysis of steel grid mechanically stabilized earth test embankments and embankments with vertical drains. M.Eng. thesis GT-90-24, Asian Institute of Technology, Bangkok, Thailand. 